\title{
Habitats Ecological Characteristics of Asplenium scolopendrium L. and its RAPD Analysis
}

\author{
Gil-Hwan Ok and Ki-Oug Yoo* \\ Department of Biological Sciences, Kangwon National University, Chuncheon 200-701, Korea
}

\begin{abstract}
This study was conducted to investigate the environmental characteristics of natural habitats, and the genetic variations in samples from 19 different quadrates of Asplenium scolopendrium 10 habitats. The natural habitats of $A$. scolopendrium were located at an altitudes $110-973 \mathrm{~m}$ with inclinations of $7-30^{\circ}$. All the quadrates were located on north facing slopes. The average field capacity of the soil is $31.4 \%$, with organic matter at $16.7 \%$, and the $\mathrm{pH}$ is 5.84 . The soil texture was confirmed as sandy loam in 8 habitats and silt loam in 2 habitats. A total of 214 vascular plants were identified from 10 habitats. The importance value of the herbaceous layer $(\mathrm{H})$ was the highest in A. scolopendrium, at $10.4 \%$, followed by Arachniodes standishii (7.3\%), Dryopteris crassirhizoma (6.5\%), and Polystichum tripteron (5.3\%), which implies that the natural habitats of $A$. scolopendrium are affinity with ferns. The species diversity of $A$. scolopendrium was estimated as on average 1.09, while the dominance and evenness were 0.12 and 0.87 , respectively. The result of the RAPD analysis, among 59 bands amplified with a primer, 25 (42.4\%) showed polymorphism. Twenty-one individuals of 10 habitats could be classified into four groups with similarity coefficient values ranging from 0.74 to 1.0. Mt. Mullae and Geumdaebong populations shows basal branching within the 21 individuals. Ulleung-do island and Jeju-do island population forms an independent clade, respectively. Mt. Moak and Byeonsan-bando clade formed a sister to the Ulleung-do island and Jeju-do island clade.
\end{abstract}

Key words - Asplenium scolopendrium, Rare plants, Vegetation, Soil analysis, RAPD analysis

\section{Introduction}

Recently, with the rising awareness of the importance of preserving biological diversity, a number of international agreements and treaties have been signed. Following this development, efforts to investigate the biotic community, and the function of ecosystems, and to prepare preservation plans for endemic plants and rare plants with limited distributions are ongoing. Research on this subject is insufficiency in Korea, although several studies on Echinosophora koreensis (Cheon et al., 2009), Hanabusaya asiatica (Jang et al., 2010), Abeliophyllum distichum (You et al., 2004), Lithospermum erythrorhizon (Ahn et al., 2009), and Abelia tyaihyoni (Jeong et al., 2007) have been carried out.

Asplenium scolopendrium L. is a perennial evergreen ferns belonging to the Aspleniaceae family. It is known to be distributed in Gangwon-do, Jeollabuk-do, Jeollanam-do, Ulleung-

${ }^{*}$ Corresponding author. E-mail : yooko@kangwon.ac.kr do island, and Jeju-do island (Lee, 1996a; Korea National Arboretum, 2008). A. scolopendrium is protected as a rare plant by Korea Forest Research Institute (1997) and designated under floristics grade III in specific plant species (Ministry of Environment, 2006). It was evaluated as "Least Concerned" in terms of endangered status.

Most previous studies of $A$. scolopendrium were conducted to habitat characteristics and vegetation structure within specific region, and horticultural utilities. Bang et al. (2004) reported on the environmental characteristics of Jeju-do island. Joo (2004) reported on the ecological characteristics and utilization in a interior landscaping. Lee and Jung (2006) and Lee (2007) reported on the mass propagation of $A$. scolopendrium.

Efforts to understand the environmental and genetic characteristics of domestic, natural populations of $A$. scolopendrium are required in order to facilitate the preparation of appropriate preservation measures.

Therefore, this research aimed to provide the basic data 
required for the protection of $A$. scolopendrium, by investigating the environmental characteristics of its natural habitats throughout Korea, and by analyzing the genetic variation status using RAPD (Randomly Amplified Polymorphic DNA).

\section{Materials and Methods}

\section{Environmental characteristics}

\section{Environmental factors}

The environmental factors of direction (Starter 1-2-3, Silva), slope (PM-5/360PC, Suunto), and altitude (GPS-V, Garmin) were recorded for each quadrates investigated in the 10 habitats of Baneul-oreum and Gyorae-ri (Jocheon-eup, Jeju-si, Jeju-do island), Teaharyeong, Nari-bunji, Dodong-ri, and Jeodong-ri (Ulleung-eup, Ulleung-do island), Geumdaebong and Mt. Mullae (Taebaek-si and Jeongseon-gun, Gangwon-do), Mt. Moak (Bulgap-myeon, Yeonggwang-gun, Jeollanam-do), Byeonsan-bando (Byeonsan-myeon, Buan-gun, Jeollabuk-do)

(Fig. 1). Nineteen quadrates sized $5 \times 5 \mathrm{~m}\left(25 \mathrm{~m}^{2}\right)$ were installed in each area.

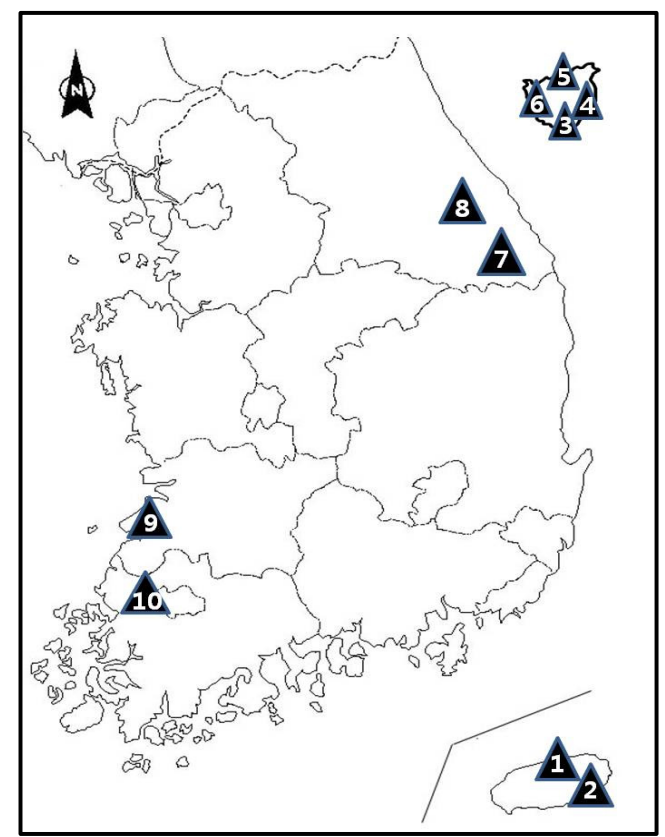

Fig. 1. Map of investigated areas (1. Gyorae-ri, 2. Baneuloreum, 3. Jeodong-ri, 4. Dodong-ri, 5. Nari-bunji, 6. Teaharyeong, 7. Geumdaebong, 8. Mt. Mullae, 9. Byeonsan-bando, 10. Mt. Moak).

\section{Soil analysis}

Surface layer of the soil was collected from each quadrates at a depth of $10 \mathrm{~cm}$, to analyze soil characteristics. Collected soil samples were brought to the laboratory and dried under shade. The soil was passed through a $2 \mathrm{~mm}$ mesh to prepare the samples for analysis. Field capacity was converted by estimating the water content from the weight of the soil before and after drying (Feodoroff and Betriemieux, 1964). Soil was mixed with distilled water, and passed through filter paper (Whatman No. 5, $90 \mathrm{~mm}, \varnothing$ ). The $\mathrm{pH}$ level was determined from the filtrate using a $\mathrm{pH}$ meter and organic matter content was measured by the loss on ignition method (Allen, 1989). The sand, silt and clay contents were measured by hydrometer, and determined soil texture based on their ratio (Kalra and Maynard, 1991).

\section{Vegetation}

Vegetation was investigated for all the vascular plant taxa which appeared within the quadrates. These vascular plant taxa were classified into the tree layer (T1: higher than $8 \mathrm{~m}$ ), sub-tree layer (T2: 2-8 m), shrub layer (S: 0.8-2 m) and herbaceous layer (H: lower than $0.8 \mathrm{~m})$. The coverage and frequency were estimated accordingly per each layer. Relative coverage (RC) and relative frequency (RF) were determined, and dominant species were decided by calculating the importance value (IV) using the following equation (Curtis and McIntosh, 1951).

Importance value $(\mathrm{IV})=\frac{\text { Relative coverage }(\mathrm{RC})+\text { Relative frequency }(\mathrm{RF})}{2}$

Additionally, species richness of the herbaceous layer (Barbour et al., 1987), species diversity (Shannon and Weaver, 1963), dominance (Simpson, 1949), and evenness (Pielou, 1975) based on the importance value were estimated, to compare the relative quantitative index of vegetation in the natural habitats. Plants were identified by referring to illustrated plant books (Lee, 1996a, 1996b; Lee, 2003; Lee, 2006), scientific name and Korean name were indicated according to the synonymic list of vascular plants in Korea (Korea National Arboretum and The Plant Toxonomic Society of Korea, 2007). 


\section{RAPD}

RAPD analysis was carried out by collecting 21 individuals from 10 habitats considering the number of quadrates at each site. Total DNA was extracted as per the method proposed by Doyle and Doyle (1987). PCR was performed in a volume of 25 ul reaction solution containing $1 \mathrm{X} \mathrm{KCl}$ buffer, $4 \mathrm{mM}$ dNTPs, $50 \mathrm{ng}$ of DNA, 0.8 unit of Taq polymerase, and $0.2 \mu$ $\mathrm{M}$ of primer. PCR was performed in a DNA Thermal Cycler (Biometra, Whatman Co.). DNA was amplified using following conditions: $94^{\circ} \mathrm{C}$ for 1 minute, $42^{\circ} \mathrm{C}$ for 1 minute, and then $72^{\circ} \mathrm{C}$ for 2 minutes, were repeated 40 times, and then further maintained at $72^{\circ} \mathrm{C}$ for 10 minutes. Amplified DNA was analyzed by electrophoresis with $1.5 \%$ agarose gel, and then photography was done under UV. As a marker to compare molecular weight, 100 bp DNA ladder was used.

Relationship analysis was performed as data matrix preparation by amplified one band as each OTU (Operational Taxonomic Unit), classifying it as 1 or 0 according to appearance of the band. Cluster analysis was carried out by NTSYS-pc (Version 2.02j, Applied Bio-statistics, Setauket, New York, USA) using UPGMA method (Unweighted Pair-group Method Using Arithmetic Average).

\section{Results and Discussion}

\section{Environmental characteristics}

\section{Environmental factors}

The degree of inclination of the natural habitats of $A$. scolopendrium showed a large variation depending on the area, ranging from $7^{\circ}$ to $60^{\circ}$. Height above sea level was in a range of $110-973 \mathrm{~m}$, and the slopes faced to the north, northwest, and northeast (Fig. 2).

Most of the natural habitats except Gyorae-ri and Baneuloreum at Gyorae-gotjawal, where water drainage was good, and conditions were hot and moist with dome shape (Bang et al., 2004), were located on slopes adjacent to valleys where soil was exposed to frequent splash erosion by increased water flow during rain, or in stony areas. Evergreen ferns like $A$. scolopendrium are associated with a developed tree layer, and are known to inhabit stony areas where drainage is good and high atmospheric humidity is maintained (Bang et al., 2004). The results of this study showed that while the distribution pattern of $A$. scolopendrium did not seem to be affected by the variations of altitude and degree of inclination, slope aspect and proximity to valleys might have a significant effect on its distribution.

\section{Soil analysis}

The organic matter content of the soil was on average $16.7 \%$ (Table 1) which was higher than the reported average organic matter content of $4.5 \%$ (Jeong et al., 2002) and of $3.2 \%$ (Lee, 1981) in the forests in Korea. This may be because

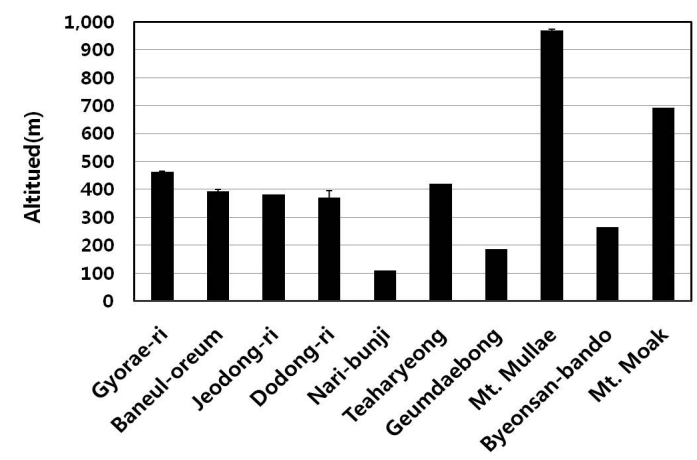

(A)

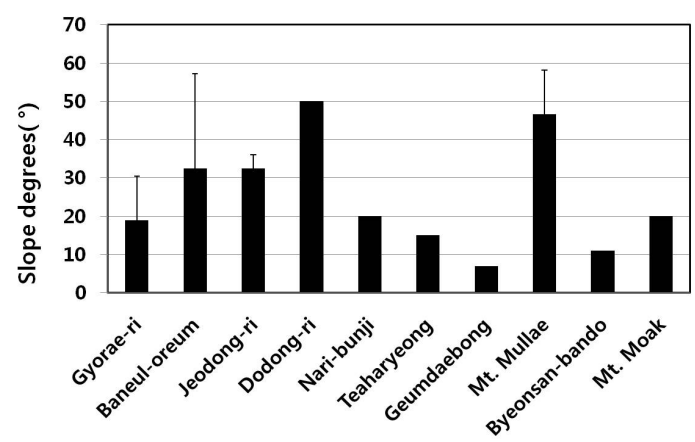

(B)

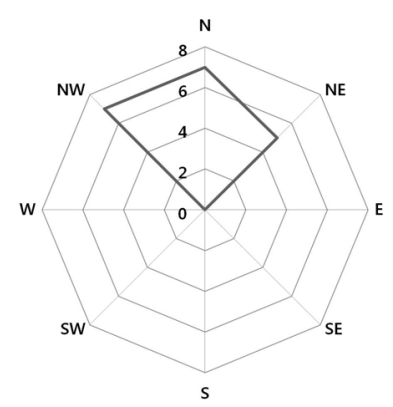

(C)

Fig. 2. Environmental characteristics of investigated sites (A: Altitude, B: Slope degrees, C: Direction). 
the developed upper tree layer in the natural habitats of $A$. scolopendrium enabled the smooth supply of organic matter such as fallen leaves and branches, and because the accumulation of organic matter was facilitated by the fact that this species inhabits valleys and stony areas where eluviation of fallen leaves is less as compared to mountain ridges and slopes. Eleven of the quadrates were from Ulleung-do island and Jeju-do island, where volcanic ash soil is a soil parent materials, and both Jeong et al. (2002) and Joo (2004) reported that $A$. scolopendrium prefers highly organic soil.

In the natural habitats of $A$. scolopendrium, $\mathrm{pH}$ level was measured in a range of 5.06-6.71 (Table 1), which is higher than the average $\mathrm{pH}$ level in Korean forest soil of 5.48 (Jeong et al., 2002). In this study, $\mathrm{pH}$ levels of soils from Mt. Mullae and Geumdaebong were higher than 6, with values 6.07 and
6.71 , respectively. This might be because the soil from these two areas is composed of limestone with neutral or alkalescent high calcium and magnesium content (Lee, 1981).

Average field capacity was confirmed as $31.4 \%$ (Table 1). This might be attributed to the organic matter supply from the upper tree layer, since even in soil with high sand and silt, once organic matter is added, clay particles bind with sticky materials produced by bacteria and Cyanophyceae, fungus, and earthworms, thereby raising the capability of holding moisture and nutrients (Kim et al., 2007).

The soil characteristics from the 10 habitats showed sandy loam in 8 and silt loam in 2. The composition ratio of the soil was found to be $34.2-73.8 \%, 22.5-59.2 \%$, and $2.5-7.5 \%$ of sand, silt, and clay respectively, while the average composition of soil from all natural habitats were $56.8 \%, 38.1 \%$, and $5.1 \%$

Table 1. Soil characteristics of investigated sites

\begin{tabular}{lccc}
\hline \hline Investigated area & Organic matter $(\%)$ & $\mathrm{pH}$ & Field capacity $(\%)$ \\
\hline Gyorae-ri & 16.5 & 5.76 & 32.5 \\
Baneul-oreum & 19.4 & 5.06 & 45.5 \\
Jeodong-ri & 14.0 & 5.72 & 25.1 \\
Dodong-ri & 13.7 & 5.78 & 26.6 \\
Nari-bunji & 13.1 & 5.91 & 27.4 \\
Teaharyeong & 16.1 & 5.66 & 35.8 \\
Geumdaebong & 21.6 & 6.71 & 44.2 \\
Mt. Mullae & 9.3 & 6.07 & 26.8 \\
Byeonsan-bando & 27.8 & 5.92 & 32.3 \\
Mt. Moak & 15.8 & 5.67 & 17.7 \\
\hline \multicolumn{1}{c}{ Average } & 16.7 & 5.84 & 31.4 \\
\hline
\end{tabular}

Table 2. Soil texture of investigated sites

\begin{tabular}{lcccc}
\hline \hline Investigated area & Sand (\%) & Silt (\%) & Clay (\%) & Texture \\
\hline Gyorae-ri & 62.5 & 34.2 & 3.3 & sandy loam \\
Baneul-oreum & 70.0 & 27.5 & 2.5 & sandy loam \\
Jeodong-ri & 73.8 & 22.5 & 3.8 & sandy loam \\
Dodong-ri & 62.5 & 30.0 & 2.5 & sandy loam \\
Nari-bunji & 58.8 & 38.8 & 2.5 & sandy loam \\
Teaharyeong & 62.5 & 35.0 & 6.7 & sandy loam \\
Geumdaebong & 34.2 & 59.2 & 7.5 & silt loam \\
Mt. Mullae & 45.8 & 46.7 & 7.5 & sandy loam \\
Byeonsan-bando & 42.5 & 50.0 & 3.5 & silt loam \\
Mt. Moak & 55.0 & 37.5 & 38.1 & sandy loam \\
\hline \multicolumn{1}{c}{ Average } & 56.8 & sandy loam \\
\hline
\end{tabular}


(Table 2). These results show that soil from natural habitats of A. scolopendrium was comprised of relatively large particles with a high sand content, as compared with the average composition ratio of forest soil in Korea of sand $37.3 \%$, silt $44.8 \%$, and clay $17.9 \%$ (Jeong et al., 2002). This may be connected to the fact that natural habitats of $A$. scolopendrium in Korea are mostly located invalleys where eluviation of fine textured soils, and splash erosion occur frequently.

\section{Vegetation}

Species diversity

The vegetation investigation showed that vascular plant taxa in 10 natural habitats of $A$. scolopendrium consisted of total 63 families, 141 genera, 187 species, 3 subspecies, 22 varieties and 2 forms, totaling 214 taxa (Table 3, Appendix 1).

As far as class is concerned, tree layer 18 taxa, subtree layer 32 taxa, shrub layers 59 taxa, and herbaceous layer 134 taxa were confirmed. The species richness of the herbaceous layer, in which A. scolopendrium is included, was highest in
Mt. Mullae, at 42 species, whereas only 12 species were found from Jeodong-ri, thus indicating large differences depending on the different natural habitats (Table 4). Generally, ferns are known to be shade plants, however more varieties of ferns are known to inhabit places where light penetrates through the boundary of trees or between tree trunks than in the forest where light does not penetrate at all (Bang et al., 2004). In the case of Mt. Mullae habitat, A. scolopendrium was distributed in valleys of coniferous forest plantation. Thus, the largest number of taxa and A. scolopendrium plants were found among the herbaceous layers in the investigated quadrates. This is because Mt. Mullae itself is a plantation area, where coverage of sub-trees and shrubs was less, and the amount of light that reached the soil surface was increased, which was beneficial for photosynthesis.

The species diversity of the herbaceous layer was estimated at 1.09 , with the highest value of 1.36 from Mt. Mullae where the largest number of taxa appeared. The lowest species diversity of the herbaceous layer was found at Byeonsan-

Table 3 . The abridged list of the plants in investigated 10 habitats

\begin{tabular}{|c|c|c|c|c|c|c|c|}
\hline Taxa/System & Fam. & Gen. & $\mathrm{Sp}$. & Subsp. & Var. & For. & Total \\
\hline Pteridophyta & 8 & 15 & 26 & . & 2 & . & 28 \\
\hline Gymnospermae & 3 & 6 & 6 & . & . & . & 6 \\
\hline Angiospermae & 52 & 120 & 155 & 3 & 20 & 2 & 180 \\
\hline Dicotyledons & 46 & 98 & 131 & 3 & 16 & 1 & 151 \\
\hline Monocotyledons & 6 & 22 & 24 & . & 4 & 1 & 29 \\
\hline Total & 63 & 141 & 187 & 3 & 22 & 2 & 214 \\
\hline
\end{tabular}

Table 4. Structural properties of herbaceous layer in investigated sites

\begin{tabular}{lcccc}
\hline \hline Investigated area & Species richness & Species diversity & Dominance & Evenness \\
\hline Gyorae-ri & 24 & 1.14 & 0.12 & 0.83 \\
Baneul-oreum & 18 & 1.08 & 0.13 & 0.86 \\
Jeodong-ri & 12 & 0.92 & 0.17 & 0.85 \\
Dodong-ri & 14 & 1.01 & 0.13 & 0.88 \\
Nari-bunji & 18 & 1.12 & 0.10 & 0.89 \\
Teaharyeong & 17 & 1.05 & 0.14 & 0.85 \\
Geumdaebong & 30 & 1.35 & 0.06 & 0.91 \\
Mt. Mullae & 42 & 1.36 & 0.08 & 0.84 \\
Byeonsan-bando & 10 & 0.88 & 0.17 & 0.88 \\
Mt. Moak & 13 & 0.98 & 0.14 & 0.88 \\
\multicolumn{1}{c}{ Average } & 19.80 & 1.09 & 0.12 & 0.87 \\
\hline
\end{tabular}


bando, at 0.88. As far as dominance was concerned, if it was higher than 0.9 , one species was dominantly distributed, whereas if dominance was in a range of $0.3-0.7$, either one species showed strong dominance, or two species were codominant. If dominance was in a range of 0.1-0.3, several species were co-dominant (Whittaker, 1965). If the dominance value was less than an average of 0.12 , vegetation of several taxa displayed even dominance.

The nearer the species evenness was to one, the higher was the evenness of distributed species (Brower and Zar, 1977). The species evenness of the investigated area was estimated as on average higher than 0.87 (Table 4), thus showing relatively even vegetation. Especially, the Geumdaebong and Mt. Mullae populations in Gangwon-do were estimated as habitats of the most even vegetation by low dominance value, high species diversity and evenness than other populations. However, species evenness from Gyorae-ri was low, at 0.83 . This might be because it is located at Gotjawal, where a stony area, and therefore overall coverage of the herbaceous layer was low, while coverage of Arachniodes standishii and Polystichum tripteron was relatively high.

\section{Importance value}

The estimated result of importance value for the herbaceous layer in natural habitats was the highest in A. scolopendrium, at $10.4 \%$ (Appendix 1) followed by Arachniodes standishii (7.3\%), Dryopteris crassirhizoma (6.5\%), and Polystichum tripteron $(5.3 \%)$. This result confirms that these taxa have a high affinity with $A$. scolopendrium. For tree layers, the highest importance value of $17.3 \%$ was found from Acer pictum subsp. mono followed by Fagus engleriana (9.4\%), Larix kaempferi (5.6\%), and Cornus controversa (5.5\%). Among the sub-tree layer, high importance values were observed from Acer palmatum (17.7\%), Acer pictum subsp. mono (10.5\%) and Acer triflorum (7.2\%). Therefore, the upper trees were mainly valley species which prefer moist areas, while ferns such as Arachniodes standishii, Dryopteris crassirhizoma, Polystichum tripteron, and Polystichum ovatopaleaceum var. coraiense showed high importance values which suggests that $A$. scolopendrium prefers the moisture and light shielding provided by the upper tree layer.

By contrast, the dominant species among the upper trees were clearly distinguished. In Ulleung-do island, the local endemic species Fagus engleriana, Tilia insularis along with Acer pictum subsp. mono were found to be the major tree species, while Acer pictum subsp. mono and Acer palmatum were found to be dominant species in Jeju-do island natural habitats. Mt. Mullae was a planted area where deciduous conifers of Larix kaempferi and Pinus densiflora were distributed. Acer pictum subsp. mono and Carpinus cordata were found in Geumdaebong, whereas in the Byeonsan-bando and Mt. Moak deciduous forests, Carpinus laxiflora, Zelkova serrata, and Acer pictum subsp. mono were found to be dominant species, which suggests that there are differences in species composition of the vegetation in each different area, as the Korean peninsula is known to show different floristic vegetation (Lee and Yim, 2002).

\section{RAPD}

RAPD analysis was carried out by selecting 7 primers (Table 5), which showed good reproducibility and amplification in all 21 samples, from among 60 random primers, with the aim of investigating the genetic variations between populations in the natural habitats for A. scolopendrium. Generally, base composition of primers influences the ability of DNA amplification (Williams et al., 1990), and higher ratio of $\mathrm{G}+\mathrm{C}$ content has been shown to be positively correlated with ability and strength of DNA amplification (Fritsch et al., 1993). Seven of the primers screened for this study successfully amplified the genomic DNAs, and $\mathrm{G}+\mathrm{C}$ contents of all the primers were higher than $60 \%$ (Table 5 ).

The size of amplified DNA bands was in a range of 200-2,900 bp with an average of 8.43 bands. The number of polymorphic bands was $25(42.4 \%)$, and the rest of the 34 (57.6\%) bands displayed monomorphic (Fig. 3).

Cluster analysis for 10 natural habitats of $A$. scolopendrium yielded a relatively high index of similarity in a range of 0.74 to 1.0 largely forming 4 clades (Fig. 4). Mt. Mullae and Geumdaebong, which are located inland with limestone as a soil parent materials, Gyorae-ri and Baneul-oreum, which consist of volcanic ash, and Jeodong-ri, Dodong-ri, Nari-bunji, and Teaharyeong, which composed another clade. Byeonsanbando and Mt. Moak, also formed one clade with a similarity of higher than 0.97 and constituted a sister group with 
Ulleung-do island and Jeju-do island.

The result implies that in the case of natural habitats in Gangwon-do, genetic diversity was high as compared with that of other areas with limestones as soil parent materials, and occurred in order to adapt to high altitude and cold weather. Mt. Moak in Jeollanam-do and Byeonsan-bando in Jeollabuk-do are located in geographically adjacent, and included in South province among 8 province classified by plant distributions in Korea (Lee and Yim, 2002). Our results support their monophyly with high similarity coefficient

Table 5. The number of RAPD bands and fragment size using seven primers of 21 samples collected from 10 investigated habitats

\begin{tabular}{ccccc}
\hline \hline Primer & Sequences $\left(5^{\prime}-3^{\prime}\right)$ & PB $^{\mathrm{z}}$ & TB & FSR (bp) \\
\hline OPA-06 & GGTCCCTGAC & 1 & 7 & $200-2,000$ \\
OPA-07 & GAAACGGGTG & 2 & 9 & $220-2,500$ \\
OPA-11 & CAATCGCCGT & 9 & 10 & $450-2,200$ \\
OPA-12 & TCGGCGATAG & 4 & 10 & $450-2,900$ \\
OPA-16 & AGCCAGCGAA & 2 & 8 & $340-2,800$ \\
OPA-19 & CAAACGTCGG & 5 & 9 & $310-2,500$ \\
OPC-02 & GTGAGGCGTC & 2 & 6 & $400-1,800$ \\
\hline
\end{tabular}

${ }^{\mathrm{z}} \mathrm{PB}$ : No. of polymorphic bands, TB: No. of total bands, FSR: fragment size range.

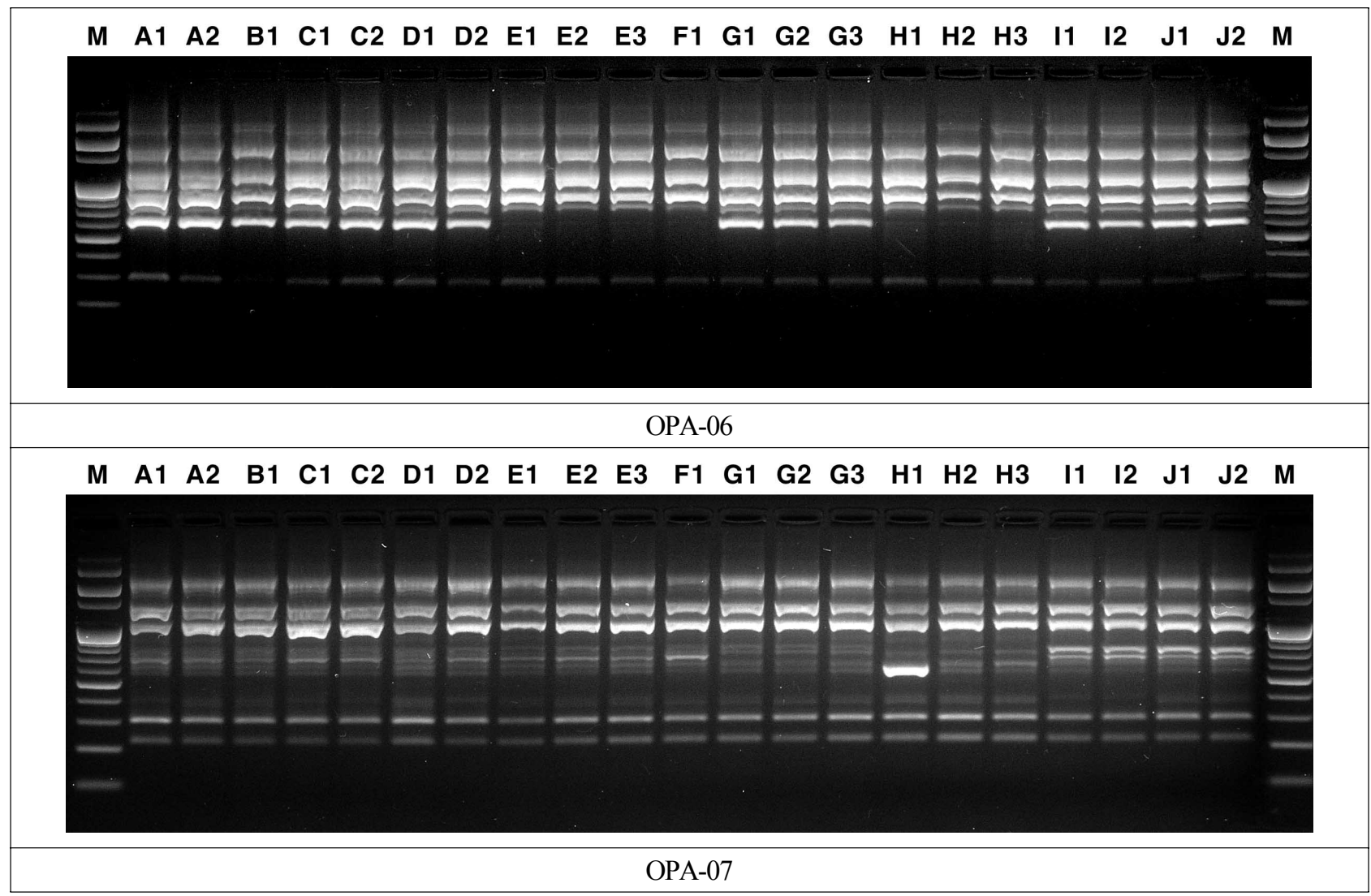

Fig. 3. RAPD profiles by OPA-06 and OPA-07 of the analyzed 21 individuals (M: 100 bp DNA ladder maker, A: Jeodong-ri, B: Dodong-ri, C: Nari-bunji, D: Teaharyeong, E: Gyorae-ri, F: Baneul-oreum, G: Geumdaebong, H: Mt. Mullae, I: Byeonsan-bando, J: Mt. Moak). 


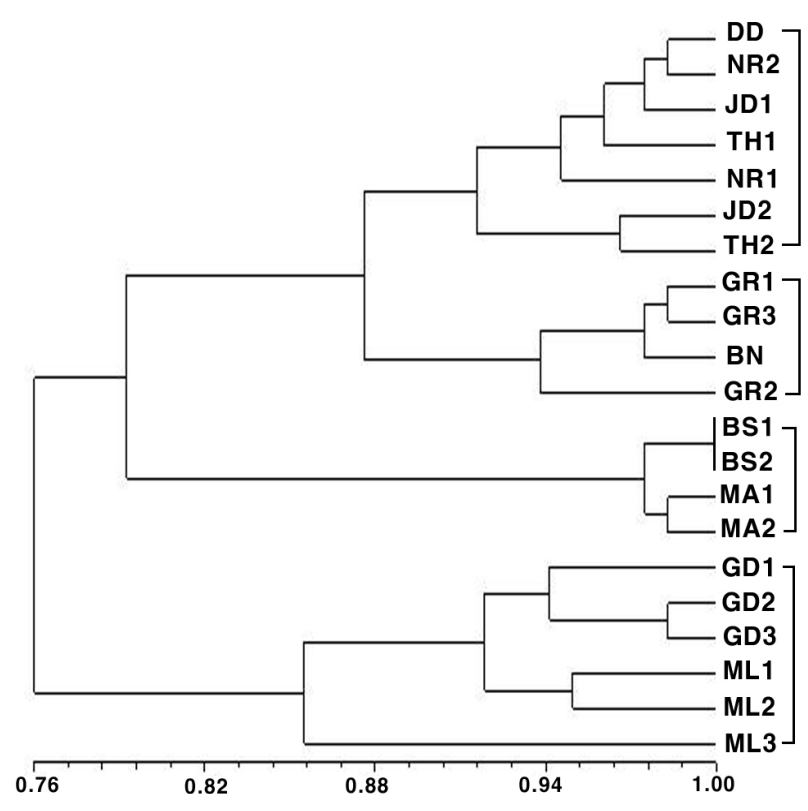

Fig. 4. Dendrogram of $A$. scolopendrium based on analysis of PCR amplified fragments produced by 7 arbitrary RAPD primers (GR: Gyorae-ri, BN: Baneul-oreum, JD: Jeodong-ri, DD: Dodong-ri, NR: Nari-bunji, TH: Teaharyeong, GD: Geumdaebong, ML: Mt. Mullae, BS: Byeonsan-bando, MA: Mt. Moak).

index between populations, and this clade is placed between 2 island and Central province clade. The genetic variation of $A$. scolopendrium in natural habitats on Jeju-do island and Ulleung-do island was less, which is assumed to be due to the warm and moist environment favorable for the growth of ferns.

RAPD analysis collectively showed a clustering tendency between the regions of geographic proximity, which suggested that natural habitats of clades with similar weather conditions and soil parent materials have significant effects on the genetic variation of $A$. scolopendrium.

\section{Literature Cited}

Ahn, Y.H., Y.H. Jin, C.Y. Choe, K.M. Lee and S.H. Lee. 2009. Ecological characteristics of Lithospermum erythrorhizon population in habitats. Kor. J. Pharmacogn. 40(4):289-297 (in Korean).

Allen, S.E. 1989. Chemical analysis of ecology materials. 2nd ed. Blackwell Scientific Publications, Oxford, UK. pp. 1-565.
Bang, K.J., K.D. Kim, H.K. Kang and J.H. Ju. 2004. Habitat characteristics and vegetation structure of the evergreen fern in Jejudo, Korea. J. Korean Env. Res. \& Reveg. Tech. 7(3): 64-72 (in Korean).

Barbour, M.G., J.H. Burk and W.D. Pitts. 1987. Terrestrial plant ecology 2nd. The Benjamin Cummings Pub. Co., California.

Brower, J.E. and J.H. Zar. 1977. Field and laboratory method for general ecology. Wm. C. Brown Co. Publishing, Iowa.

Cheon, K.S., S.K. Jang, W.T. Lee and K.O. Yoo. 2009. The natural habitat and distribution of Echinosophora koreensis (Nakai) Nakai in Korea. Korean J. Pl. Taxon. 39(4):254-263 (in Korean).

Curtis, J.T. and R.P. McIntosh. 1951. An upland forest continuum in the prairie forest bolder region Wisconsin. Ecology 32: 476-496.

Doyle, J.J. and J.S. Doyle. 1987. A rapid DNA isolation procedure for small quantities of fresh leaf tissue. Phytochem. Bull. 19:11-15.

Feodoroff, A. and R. Betriemieux. 1964. Une methods de laboratoire pour la determination de la capacite au champ. Science du sol. p. 109.

Fritsch, P., M.A. Hanson, C.D. Spore, P.E. Pack and L.H. Reiseberg. 1993. Constancy of RAPD primer amplification strength among distantly related taxa of flowering plants. Plant Mol. Biol. 11:10-20.

Jang, S.K., K.S. Cheon, J.H. Jeong, Z.S. Kim and K.O. Yoo. 2010. Environmental characteristics and vegetation of Hanabusaya asiatica habitats. Kor. J. Hort. Sci. Technol. 28(3):497-506 (in Korean).

Jeong, J.H., K.S. Koo, C.H. Lee and C.S. Kim. 2002. Physicochemical properties of Korean forest soils by regions. Jour. Korean For. Soc. 91(6):694-700 (in Korean).

Jeong, J.H., K.S. Kim C.H. Lee and Z.S. Kim. 2007. Genetic diversity and spatial structure in populations of Abelia tyaihyoni. Jour. Korean For. Soc. 96(6):667-675 (in Korean).

Jo, D.G., S.C. Ko, H.T. Im, W.K. Paik, G.Y. Chung, C.Y. Yoon, K.O. Yoo, C.G. Jang and S.H. Kang. 2009. Distribution maps of vascular plants of Korean peninsula. Vol. 6. Central province (Gangwon-do). Korea National Arboretum, Pocheon, Korea. pp. 1-793 (in Korean).

Joo, J.H. 2004. Ecological charateristics and using feasibility of evergreen ferns native to Korea for interior landscaping. Ph.D. Thesis, Sangmyung National University. pp. 1-124 (in Korean).

Kalra, Y.P. and D.G. Maynard. 1991. Methods manual for 
forest soil and plant analysis. Canadian Forest Service, Edmonton, Canada. pp. 1-116.

Kim, J.H., K.H. Suh, Y.S. Choung, K.S. Lee, S.D. Koh, J.S. Lee, B.S. Ihm, H.T. Mun, K.H. Cho, H.S. Lee, Y.H. You, B.M. Min, C.S. Lee, E.J. Lee and K.H. Oh. 2007. Current Ecology. Kyomunsa Publishing Co., Seoul, Korea. pp. 1-434 (in Korean).

Kim, K.H., B.C. Lee and S.C. Hong. 1993. Ecological studies on the vegetational characteristics of the virgin forests of Songin-bong in Ulreung Island, Korea. Jour. Korean For. Soc. 82(2):139-151 (in Korean).

Korea Forest Research Institute. 1997. Illustrated rare and endangered species in Korea. Korea Forest Research Institute, Seoul, Korea. (in Korean).

Korea National Arboretum. 2008. Illustrated Pteridophytes of Korea. Korea National Arboretum, Pocheon, Korea. pp. 1-547 (in Korean). and The Plant Taxonomic Society of Korea. 2007. A synonymic list of vascular plants in Korea. Korea National Arboretum, Pocheon, Korea. pp. 1-534 (in Korean).

Lee, S.W. 1981. Studies on forest soils in Korea. Jour. Korean For. Soc. 54(1):25-35 (in Korean).

Lee, T.B. 2003. Coloured Flora of Korea (Ha). Hyangmunsa Publishing Co., Seoul, Korea. pp. 1-914 (in Korean).

Lee, W.T. 1996a. Lineamenta Flarae Koreae. Academy Publishing Co., Seoul, Korea. pp. 1-624 (in Korean).

. 1996b. Standard Illustrations of Korean Plants. Academy

Publishing Co., Seoul, Korea. pp. 1-1688 (in Korean). and Y.J. Yim. 2002. Plant Geography. Kangwon National

University Press. Chuncheon, Korea. pp. 1-412 (in Korean).

Lee, Y.H.. 2007. Mass propagation of Korea green native ferns in vitro for developing materials of interior landscape architecture. J. Korean Soc. People Plants Environ. 10(3): 65-73 (in Korean).

and H.H. Jung. 2006. Mass propagation of Korea green native ferns in vitro for developing materials of interior landscape architecture. Soonchunhyang J. Nat. Sci. 12(2): 107-112 (in Korean).

Lee, Y.N. 2006. New Flora of Korea (II). Gyohaksa Publishing Co., Seoul, Korea. pp. 1-885 (in Korean).

Ministry of Environment. 2006. The investigation guide for specially designated species by floristic region. 3rd ed. Ministry of Environment, Gwacheon, Korea. (in Korean).

Pielou, E.C. 1975. Mathematical ecology. John Wiley \& Sons, New York, USA. p. 385.

Shannon, C.E. and W. Weaver. 1963. The mathematical theory of communication. Univ. Illinois Press, Urbana, USA. pp. $1-125$.

Simpson, E.H. 1949. Measurement of diversity. Nature 163:688.

Song, H.K. and S. Yee. 2000. Soil characteristics in Fagus multinervis sub communities at Songinbong area of Ullungdo. Korean J. Environ. Biol. 18(3):299-305 (in Korean).

Whittaker, R.H. 1965. Dominance and diversity in land plant communities. Science 147: 250-260.

Williams, J.G.K., A.R.K Kubelik, J. Livak, J.A. Rafalski and S.V. Tingey. 1990. DNA polymorphism amplified by arbitrary primers are useful as genetic markers. Nucleic Acids Res. 18:6531-6535.

You, J.H., H.W. Cho, S.G. Jung and C.H. Lee. 2004. Correlation analysis between growth and environmental characteristics in Abeliophyllum distichum habitats. Korean. J. Env. Eco. 18(2):210-220 (in Korean). 
Korean J. Plant Res. 25(6) : 719 730 (2012)

Appendix 1. Importance value of species in investigated sites

\begin{tabular}{|c|c|c|c|c|c|c|c|c|c|c|c|c|c|c|c|c|c|c|}
\hline \multirow{2}{*}{ Layer } & \multirow{2}{*}{ Species } & \multicolumn{3}{|c|}{ 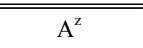 } & \multirow{2}{*}{$\begin{array}{l}\mathrm{B} \\
1\end{array}$} & $\overline{\mathrm{C}}$ & \multirow{2}{*}{$\begin{array}{l}\mathrm{D} \\
1\end{array}$} & \multicolumn{2}{|c|}{ E } & \multicolumn{2}{|l|}{ F } & \multicolumn{2}{|l|}{ G } & \multicolumn{2}{|r|}{$\overline{\mathrm{H}}$} & \multirow{2}{*}{$\begin{array}{cc} & \mathrm{H} \\
3 & 1\end{array}$} & \multirow{2}{*}{$\frac{\mathrm{J}}{1}$} & \multirow{2}{*}{ IV } \\
\hline & & 1 & 2 & 3 & & 1 & & 11 & 2 & 1 & 2 & 2 & 3 & 1 & 2 & & & \\
\hline \multirow{18}{*}{$\mathrm{T}^{\mathrm{y}}$} & Acer pictum subsp. mono (Maxim.) Ohashi 고로쇠나무 & & 2.5 & 13 & & 0.1 & & & 3.8 & 5.1 & & 4.4 & & & & & 0.1 & $14.5^{\mathrm{x}}$ \\
\hline & Fagus engleriana Seemen ex Diels 너도밤나무 & & & & & & & 6.6 & 2.6 & & 5.3 & & & & & & & 9.4 \\
\hline & Larix kaempferi (Lamb.) Carriere 일본잎갈나무 & & & & & & & & & & & & & 3.4 & & 6.0 & & 5.6 \\
\hline & Cornus controversa Hemsl. ex Prain 층층나무 & & & & & & & & & & & & & & & & 5.6 & 5.5 \\
\hline & Cornus walteri F.T.Wangerin 말채나무 & & & & & & 5.5 & .5 & & & & & & & & & & 5.4 \\
\hline & Carpinus cordata Blume 까치박달 & & & & & & & & & & & & 5.4 & & & 0.1 & & 5.4 \\
\hline & Cryptomeria japonica (L.f.) D.Don 삼나무 & & & & & 4.31 .1 & 1.1 & & & & & & & & & & & 4.7 \\
\hline & Zelkova serrata (Thunb.) Makino 느티나무 & & & & & & & & & & & & & & & 4.7 & & 4.5 \\
\hline & Acer palmatum Thunb. ex Murray 단풍나무 & & 3.0 & & & & & & & & & & & & & & 1.5 & 3.8 \\
\hline & Actinidia arguta (Siebold \& Zucc.) Planch. ex Miq. 다래 & & & & & & & & & & & & & 3.00 & 0.8 & & & 3.8 \\
\hline & Morus bombycis Koidz. 산뽕나무 & 3.8 & & & & & & & & & & & & & & & & 3.2 \\
\hline & Acer triflorum Kom. 복자기 & & & & & & & & & & & 3.2 & & & & & & 2.9 \\
\hline & Lindera erythrocarpa Makino 비목나무 & & & 2.9 & & & & & & & & & & & & & & 2.9 \\
\hline & Cornus macrophylla Wall. 곰의말채나무 & & & 2.9 & & & & & & & & & & & & & & 2.9 \\
\hline & Pinus densiflora Siebold \& Zucc. 소나무 & & & & & & & & & & & & & & 2.9 & & & 2.9 \\
\hline & Salix koreensis Andersson 버드나무 & & & & & & & & & & & & & & 2.9 & & & 2.9 \\
\hline & Carpinus laxiflora (Siebold \& Zucc.) Blume 서어나무 & & & & & & & & & & & & & & & 2.7 & & 2.7 \\
\hline & Vitis flexuosa Thunb. 새머루 & & & & & & & & & & & & & & 1.8 & & & 1.8 \\
\hline \multirow{29}{*}{$\mathrm{T} 2$} & Acer palmatum Thunb. ex Murray 단풍나무 & 4.7 & 6.32 & 2.0 & 2.3 & & & & & & & & & & & 2.3 & & 17.7 \\
\hline & Acer pictum subsp. mono (Maxim.) Ohashi 고로쇠나무 & & & & & & 6.7 & & 2.5 & 1.3 & & & & & & & & 10.5 \\
\hline & Acer triflorum Kom. 복자기 & & & & & & & & & & 0.7 & 7 & 6.5 & & & & & 7.2 \\
\hline & Euonymus macropterus Rupr. 나래회나무 & & & & & & & & & & 4.5 & 51.8 & & & & 0.9 & & 7.1 \\
\hline & Tilia insularis Nakai 섬피나무 & & & & & & & & & 5.21 & 1.5 & & & & & & & 6.7 \\
\hline & Styrax obassia Siebold \& Zucc. 쪽동백나무 & & & & & & & & & 1.24 & 4.1 & & & & & & & 5.4 \\
\hline & Acer takesimense Nakai 섬단풍나무 & & & & & & & & 2.0 & & 2.0 & & & & & & & 4.1 \\
\hline & Orixa japonica Thunb. 상산 & & & & 1.5 & & & & & & & & & & & 1.5 & & 3.0 \\
\hline & Quercus mongolica Fisch. ex Ledeb. 신갈나무 & & & & & & & & & & 2.7 & 7 & & & 0.1 & & & 2.8 \\
\hline & Sambucus sieboldiana var. pendula (Nakai) T.B.Lee 말오줌나무 & & & & & & 2.6 & 6 & & & & & & & & & & 2.6 \\
\hline & Cornus kousa F.Buerger ex Miquel 산딸나무 & 2.6 & & & & & & & & & & & & & & & & 2.6 \\
\hline & Acer ukurunduense Trautv. \& C.A.Mey. 부게꽃나무 & & & & & & & & & & & 2.6 & & & & & & 2.6 \\
\hline & Hedera rhombea (Miq.) Bean 송악 & & & & 2.1 & & & & & & & & & & & & 0.2 & 2.3 \\
\hline & Hydrangea petiolaris Siebold \& Zucc. 등수국 & & 1.01 & 1.0 & & & & & & & & & & & & & & 2.1 \\
\hline & Carpinus cordata Blume 까치박달 & & & & & & & & & & 2.0 & 0 & & & & & & 2.0 \\
\hline & Acer pseudosieboldianum (Pax) Kom. 당단풍나무 & & & & & & & & & & & 2.0 & & & & & & 2.0 \\
\hline & Cinnamomum japonicum Siebold ex Nees 생달나무 & & 1.8 & & & & & & & & & & & & & & & 1.8 \\
\hline & Ligustrum obtusifolium Siebold \& Zucc. 쥐뜽나무 & & & 1.8 & & & & & & & & & & & & & & 1.8 \\
\hline & Sorbus commixta Hedl. 마가목 & & & & & & & & 1.5 & & & & & & & & & 1.5 \\
\hline & Lindera erythrocarpa Makino 비목나무 & & & 1.5 & & & & & & & & & & & & & & 1.5 \\
\hline & Prunus takesimensis Nakai 섬벚나무 & & & & & & .3 & & & & & & & & & & & 1.3 \\
\hline & Ficus erecta Thunb. 천선과나무 & & & 1.3 & & & & & & & & & & & & & & 1.3 \\
\hline & Acer tataricum subsp. ginnala (Maxim.) Wesm. 신나무 & & & & & & & & & & & & & 1.3 & & & & 1.3 \\
\hline & Neolitsea sericea (Blume) Koidz. 참식나무 & & & & & 1.0 & & & & & & & & & & & & 1.0 \\
\hline & Cryptomeria japonica (L.f.) D.Don 삼나무 & & & & & 1.0 & & & & & & & & & & & & 1.0 \\
\hline & Celtis jessoensis Koidz. 풍게나무 & & & & & & .0 & & & & & & & & & & & 1.0 \\
\hline & Celastrus flagellaris Rupr. 푼지나무 & & & & & & & & 1.0 & & & & & & & & & 1.0 \\
\hline & Camellia japonica L. 동백나무 & & & & & & & & & & 1.0 & & & & & & & 1.0 \\
\hline & Euonymus fortunei var. radicans (Miq.) Rehder 줄사철나무 & & 1.0 & & & & & & & & & & & & & & & 1.0 \\
\hline
\end{tabular}


Appendix 1. Continued

\begin{tabular}{|c|c|c|c|c|c|c|c|c|c|c|c|c|c|c|c|c|c|c|c|c|}
\hline \multirow{2}{*}{ Layer } & \multirow{2}{*}{ Species } & \multicolumn{3}{|c|}{ A } & \multirow{2}{*}{$\begin{array}{l}\mathrm{B} \\
1 \\
\end{array}$} & $\mathrm{C}$ & \multirow{2}{*}{$\begin{array}{l}\mathrm{D} \\
1\end{array}$} & \multicolumn{2}{|c|}{ E } & \multicolumn{2}{|l|}{$\mathrm{F}$} & \multicolumn{3}{|c|}{ G } & \multicolumn{3}{|c|}{$\mathrm{H}$} & \multirow{2}{*}{$\begin{array}{c}\mathrm{H} \\
1 \\
\end{array}$} & \multirow{2}{*}{$\frac{\mathrm{J}}{1}$} & \multirow{2}{*}{ IV } \\
\hline & & 1 & 2 & 31 & & 12 & & 1 & 2 & 1 & 2 & 1 & 2 & 3 & 1 & 2 & 3 & & & \\
\hline \multirow{3}{*}{$\mathrm{T} 2$} & Fagus engleriana Seemen ex Diels 너도밤나무 & & & 1.0 & & & & & & & & & & & & & & & & 1.0 \\
\hline & Torreya nucifera $($ L.) Siebold \& Zucc. 비자나무 & & & & & & & & & & & & & & & & & & 1.0 & 1.0 \\
\hline & Morus bombycis Koidz. 산뽕나무 & & & & & & & & & & & & & & & 1.0 & & & & 1.0 \\
\hline & Orixa japonica Thunb. 상산 & 3.5 & 4.9 & 0.53. & 3.5 & & & & & & & & & & & & & 3.0 & & 15.4 \\
\hline & Hedera rhombea (Miq.) Bean 송악 & 0.1 & 0.1 & 0.10. & 0.10 .1 & 10.1 & 1.6 & 3.3 & 0.1 & 4.1 & 0.1 & & & & & & & & & 9.7 \\
\hline & Ligustrum obtusifolium Siebold \& Zucc. 쥐똥나무 & & 0.92 & 2.7 & & & 0.1 & & 0.1 & & & & & & & & & 0.9 & 0.1 & 4.8 \\
\hline & Philadelphus schrenkii Rupr. 고광나무 & & & & & & & & & & & & & & 3.1 & 1.0 & & & & 4.2 \\
\hline & Camellia japonica $\mathrm{L}$. 동백나무 & & & & & & 0.1 & & & 1.9 & 1.9 & & & & & & & & & 3.8 \\
\hline & Boehmeria spicata (Thunb.) Thunb. 좀깨잎나무 & & & & 3.3 & 30.1 & & & & & & & & & & & & & & 3.4 \\
\hline & Hydrangea petiolaris Siebold \& Zucc. 등수국 & 0.1 & & 0.1 & & & & 0.1 & 1.4 & & 1.4 & & & & & & & & & 3.2 \\
\hline & Stephanandra incisa (Thunb.) Zabel 국수나무 & & & & & & & & & & & & & & 2.9 & 0.1 & 0.1 & & & 3.0 \\
\hline & Euonymus fortunei var. radicans (Miq.) Rehder 줄사철나무 & 0.1 & & & & 2.5 & & & & & & & & & & & & & & 2.6 \\
\hline & Deutzia glabrata Kom. 물참대 & & & & & & & & & & & & 1.3 & 1.3 & & & & & & 2.5 \\
\hline & Trachelospermum asiaticum (Siebold \& Zucc.) Nakai 마삭줄 & 0.5 & 0.5 & 0.50. & 0.5 & & & & & & & & & & & & & & 0.5 & 2.4 \\
\hline & Hydrangea paniculata Siebold 나무수국 & & & & 2.1 & .1 & & & & & & & & & & & & & & 2.1 \\
\hline & Acer ukurunduense Trautv. \& C.A.Mey. 부게꽃나무 & & & & & & & & & & & & 2.1 & & & & & & & 2.1 \\
\hline$S$ & Morus bombycis Koidz. 산뽕나무 & & & & & 0.2 & & & & & & & & & & 1.5 & 0.2 & & & 1.8 \\
\hline $\mathrm{S}$ & Lindera obtusiloba Blume 생강나무 & & & & & & & & & & & & & & & 1.5 & 0.2 & 0.2 & & 1.8 \\
\hline & Rubus oldhamii Miq. 줄딸기 & & & & & & & & & & & & & & 0.2 & 0.2 & 1.5 & & & 1.8 \\
\hline & Euonymus macropterus Rupr. 나래회나무 & & & & & & & & & & & 1.7 & & 0.1 & & & & & & 1.7 \\
\hline & Acer tataricum subsp. ginnala (Maxim.) Wesm. 신나무 & & & & & & & & & & 1.7 & & & & & & & & & 1.7 \\
\hline & Ribes mandshuricum (Maxim.) Kom. 까치밥나무 & & & & & & & & & & & & & & & & & 1.7 & & 1.7 \\
\hline & Smilax sieboldii Miq. 청가시덩굴 & & & & & & & & & & & & & & 0.5 & 0.5 & 0.5 & & & 1.5 \\
\hline & Taxus cuspidata Siebold \& Zucc. 주목 & & & & & & & 1.2 & 0.1 & & & & & & & & & & & 1.3 \\
\hline & Daphniphyllum macropodum Miq. 굴거리나무 & & & & & & & & & 0.1 & 1.2 & & & & & & & & & 1.3 \\
\hline & Rubus crataegifolius Bunge 산딸기 & & & & & & & & & & & & & & 0.1 & & 1.2 & & & 1.3 \\
\hline & Malus baccata Borkh. 야광나무 & & & & & & & & & & & & & & & & & 1.3 & & 1.3 \\
\hline & Deutzia grandiflora var. baroniana Diels 바위말발도리 & & & & & & & & & & & 1.3 & & & & & & & & 1.3 \\
\hline & Euonymus alatus for. ciliatodentatus (Franch. \& Sav.) Hiyama 회잎나무 & & & & & & & & & & & & 1.3 & & & & & & & 1.3 \\
\hline & Acer tegmentosum Maxim. 산겨릅나무 & & & & & & & & & & & & & 1.3 & & & & & & 1.3 \\
\hline & Prunus padus $\mathrm{L}$. 귀룽나무 & & & & & & & & & & & & & 1.3 & & & & & & 1.3 \\
\hline & Asplenium scolopendrium L. 골고사리 & 0.4 & 0.4 & & 1.8 & 8 & & & & 0.4 & 0.4 & 0.7 & 1.5 & & 0.4 & 2.2 & 1.8 & 0.4 & & 10.4 \\
\hline & Arachniodes standishii (T.Moore) Ohwi 일색고사리 & & & 1.6 & & & & 1.3 & 0.3 & 3.8 & 0.3 & & & & & & & & & 7.3 \\
\hline & Dryopteris crassirhizoma Nakai 관중 & & & & & & & 1.6 & 0.4 & & & & 1.21 & 1.6 & 0.8 & 0.4 & 0.4 & & & 6.5 \\
\hline & Polystichum tripteron (Kunze) C.Presl 십자고사리 & 1.7 & 1.0 & 0.7 & & & & & & & & & & & & & 0.3 & & 1.4 & 5.3 \\
\hline & Polystichum ovatopaleaceum var. coraiense (H.Christ) Sa.Kurata 참나도히초미 & & & & 0.71 .4 & 40.7 & & & & & & & & & & & & & & 3.0 \\
\hline & Vicia venosa var. albiflora (Turcz.) Maxim. 큰네잎갈퀴 & & & & & & & & & & & & & & 1.5 & & 1.2 & & & 2.6 \\
\hline & Torilis japonica (Houtt.) DC. 사상자 & & & & 2.2 & & & & & & & & & & & & & & & 2.3 \\
\hline $\mathrm{H}$ & Achyranthes japonica (Miq.) Nakai 쇠무릎 & & & & & 0.3 & 1.7 & & & & & & & & & & & & & 2.1 \\
\hline & Corydalis remota Fisch. ex Maxim. 현호색 & & & & & & & & & & & & & & & & & 1.9 & & 2.0 \\
\hline & Polystichum retrosopaleaceum (Kodama) Tagawa 비늘개관중 & & & & & & & & 0.7 & 1.1 & & & & & & & & & & 1.8 \\
\hline & Aruncus dioicus var. kamtschaticus (Maxim.) H.Hara 눈개승마 & & & & & & & & & & & 1.1 & 0.40 & 0.4 & & & & & & 1.8 \\
\hline & Phryma leptostachya var. asiatica H.Hara 파리풀 & & & & 1.4 & 40.1 & & 0.1 & 0.1 & 0.1 & & & & & & & 0.1 & & & 1.7 \\
\hline & Farfugium japonicum (L.) Kitam. 털머위 & & & & & & 1.6 & & & & & & & & & & & & & 1.6 \\
\hline & Cayratia japonica (Thunb.) Gagnep. 거지덩굴 & & & & & & 1.4 & & & & & & & & & & & & & 1.5 \\
\hline & Pilea japonica (Maxim.) Hand.-Mazz. 산물통이 & & & & & & & & & & & & & & & & & & 1.4 & 1.4 \\
\hline & Adiantum pedatum $\mathrm{L}$. 공작고사리 & & & & & & & & & 0.3 & 1.0 & & & & & & & & & 1.4 \\
\hline
\end{tabular}


Korean J. Plant Res. 25(6) : 719 730 (2012)

\section{Appendix 1. Continued}

\begin{tabular}{|c|c|c|c|c|c|c|c|c|c|c|c|c|c|c|c|c|c|c|c|c|c|}
\hline \multirow{2}{*}{ Layer } & \multirow{2}{*}{ Species } & \multicolumn{3}{|c|}{$\overline{\mathrm{A}}$} & \multirow{2}{*}{$\begin{array}{l}\mathrm{B} \\
1\end{array}$} & \multicolumn{2}{|c|}{$\mathrm{C}$} & \multirow{2}{*}{$\begin{array}{l}\mathrm{D} \\
1 \\
\end{array}$} & \multicolumn{2}{|c|}{$\mathrm{E}$} & \multicolumn{2}{|c|}{$\mathrm{F}$} & \multicolumn{3}{|c|}{ G } & \multicolumn{3}{|c|}{$\mathrm{H}$} & \multirow{2}{*}{$\begin{array}{c}\mathrm{H} \\
1\end{array}$} & \multirow{2}{*}{$\frac{\mathrm{J}}{1}$} & \multirow[t]{2}{*}{ IV } \\
\hline & & 1 & 2 & 3 & & 1 & 2 & & 1 & 2 & 1 & 2 & 1 & 2 & 3 & 1 & 2 & 3 & & & \\
\hline \multirow{10}{*}{$\mathrm{H}$} & Isodon inflexus (Thunb.) Kudo 산박하 & & & 0.1 & & & & & & & & & & & & 1.1 & 0.1 & 0.1 & & & 1.3 \\
\hline & Saussurea grandifolia Maxim. 서덜취 & & & & & & & & & & 0.1 & & 0.6 & 0.6 & 0.1 & & & & & & 1.3 \\
\hline & Athyrium niponicum (Mett.) Hance 개고사리 & 0.1 & 0.1 & 0.9 & & & & 0.1 & & & & & & & & & & 0.1 & & & 1.2 \\
\hline & Asperula odorata L. 선갈퀴 & & & & & & & & & & & & & & & & & & 1.2 & & 1.2 \\
\hline & Boehmeria longispica Steud. 왜모시풀 & & & & & & & & & & & & & & & & & 1.1 & & & 1.1 \\
\hline & Deparia pycnosora (H.Christ) M.Kato 털고사리 & & & & & & & & & & & & & 1.0 & & & & & & & 1.1 \\
\hline & Hepatica maxima Nakai 섬노루귀 & & & & & & & & 0.5 & 0.5 & & 0.1 & & & & & & & & & 1.1 \\
\hline & Anemone raddeana Regel 뀡의바람꽃 & & & & & & & & & & & & 0.5 & 0.5 & 0.1 & & & & & & 1.1 \\
\hline & Cimicifuga dahurica (Turcz. ex Fisch. \& C.A.Mey.) Maxim. 눈빛승마 & & & & & & & & & & & & 0.5 & 0.5 & 0.1 & & & & & & 1.1 \\
\hline & Smilacina japonica A.Gray 풀솜대 & & & & 0.1 & & & & & & & & 0.1 & 0.1 & 0.8 & & & & & & 1.0 \\
\hline
\end{tabular}

${ }^{\mathrm{z}}$ A: Gyorae-ri, B: Baneul-oreum, C: Jeodong-ri, D: Dodong-ri, E: Nari-bunji, F: Teaharyeong, G: Geumdaebong, H: Mt. Mullae, I: Byeonsan-bando, J: Mt. Moak.

${ }^{\mathrm{y}} \mathrm{T} 1$ : Tree layer, T2: Subtree layer, S: Shrub layer, H: Herbaceous layer, IV: Importance value.

${ }^{\mathrm{x}}$ Plant taxa which are evaluated low importance value $(<1.0)$ are excluded. 